\title{
16. PETROLOGY OF THE BASALTIC ROCKS OF THE NANKAI TROUGH BASEMENT ${ }^{1}$
}

\author{
F. Siena,${ }^{2}$ M. Coltorti, ${ }^{2}$ E. Saccani, ${ }^{2}$ and C. Vaccaro ${ }^{2}$
}

\begin{abstract}
Major- and trace-element analyses, mineral chemistry, and $\mathrm{Sr}$-Nd isotopic determinations were obtained on representative igneous rocks drilled from the Nankai accretionary complex (Site 808) during Ocean Drilling Program Leg 131. For the first time, the oceanic basement of the subducting plate below an accretionary prism has been reached. The Nankai Trough basement was encountered at a depth of $1289.9 \mathrm{mbsf}$ and a total of $37.1 \mathrm{~m}$ of igneous rocks, middle Miocene (15.6 Ma) in age, was penetrated.

Two main lithological units have been distinguished from the top downward; sill-like rocks (Unit I: Cores 105, 106, 107) and pillow lavas (Unit II: Core 108). Basalts are predominantly nonvesicular, hypocrystalline, aphyric to slightly phyric with intersertal to intergranular textures. Alteration is generally slight to moderate. All the basaltic rocks are cut by ramifying veins of varying widths. Secondary mineral assemblages (including vein fillings) are typical of submarine alteration and zeolite to low greenschist facies metamorphism.

The order of crystallization of primary minerals is: olivine, plagioclase, clinopyroxene. This, together with mineral chemistry, characterized by forsteritic olivine (Fo 84-85), highly anorthitic plagioclase (up to An 90), and in particular the composition of clinopyroxene, are typical of normal mid-ocean ridge basalts (MORB).

In terms of $\mathrm{Zr} / \mathrm{Y}(2.9-3.8)$ and $\mathrm{Zr} / \mathrm{Nb}$ (21-58), all the analyzed samples plot in the normal MORB field. The chondrite-normalized REE patterns confirm the close affinity with normal MORB type $\left(\mathrm{La}_{N} / \mathrm{Sm}_{\mathrm{N}}: 0.6-0.8\right)$. Note that such magmatism does not reveal any evidence of subduction-related geochemical components. The ${ }^{87} \mathrm{Sr} /{ }^{86} \mathrm{Sr}$ isotopic ratios range from 0.70339 in pillow lavas to 0.70317 in the least-altered basalts of sill units (ratios reduced to $0.70265-0.70271$ by $\mathrm{HCl} 2.5 \mathrm{~N}$ hot leaching), whereas ${ }^{143} \mathrm{Nd} /{ }^{144} \mathrm{Nd}$ ratios are $0.51314-0.51326$. These values conform with those of normal MORB.

Stratigraphy, petrography, and geochemistry of the basaltic rocks recovered at Site 808 appear very similar to those from the Shikoku Basin basement (particularly Sites 442 and 443, DSDP Leg 58), analogously identified as normal MORB.
\end{abstract}

\section{INTRODUCTION}

The Nankai Trough marks the subduction boundary between the Shikoku Basin (oceanic Philippine Sea Plate) and the southwest Japan arc (continental Eurasian Plate). The Shikoku Basin was formed as a backarc basin behind the Izu-Bonin arc by mostly east-west (and later northeast-southwest) spreading episodes during late Oligocene to middle Miocene ( 25 to $15 \mathrm{Ma}$ ) (Kobayashi and Nakada, 1978; Shih, 1980; Chamot-Rooke et al., 1987). The fossil spreading axis lies in the central part of the Shikoku Basin and is being subducted at the central sector of the Nankai Trough. The accretionary complex is one of the best-known clastic prism complexes and is continuous from the present deformation front in the Nankai Trough to the CretaceousTertiary accretionary complex, the Shimanto Belt, which crops out in the neighboring areas of the southwest Japan arc (Fig. 1).

Ocean Drilling Program (ODP) Site 808 (Leg 131) is located in the accreted and deformed sediments at the toe of the prism, and immediately eastward of the subducting fossil-spreading axis of the Shikoku Basin.

Previous drilling in the Nankai region (Deep Sea Drilling Project [DSDP] Sites 298, 582, 583) never reached the basement. At Site 808, for the first time in ocean drilling history, the oceanic basement below an accretionary complex was reached. The basement rocks were encountered in Hole $808 \mathrm{C}$ at a depth of $1289.9 \mathrm{mbsf}$, and a total of $37.1 \mathrm{~m}$ of igneous rocks were penetrated. About $300 \mathrm{~m}$ of hemipelagic sediments, directly overlying the basement of the subducting oceanic plate, were drilled beneath the décollement zone ( $945-964 \mathrm{mbsf})$. The basaltic basement rocks of the Nankai region are middle Miocene $(15.6 \mathrm{Ma})$ in age on the basis of calcareous nannofossils (Shipboard Scientific Party, 1990), found in some intercalated baked sediments.

\footnotetext{
${ }^{1}$ Hill, I.A., Taira, A., Firth, J.V., et al., 1993. Proc. ODP, Sci. Results, 131: College Station, TX (Ocean Drilling Program).

${ }^{2}$ Istituto di Mineralogia, Università di Ferrara, Corso Ercole I D'Este, 32, 44100 Ferrara, Italy.
}

In this paper, major- and trace-element analyses, mineral chemistry, and $\mathrm{Sr}-\mathrm{Nd}$ isotopic data are reported for representative igneous rocks of Site 808 with the aim of defining the petrological nature of the Nankai Trough basement.

\section{PETROGRAPHY}

Depths, recovery, lithostratigraphy, and synthetic petrographic description of the basement basaltic rocks are summarized in Figure 2. On the basis of mineralogy, texture, and geochemical characteristics, two main lithological units have been distinguished from the top downward: sill-like rocks (Unit I: Cores 105, 106, 107) and pillow lavas (Unit II: Core 108), of basaltic composition. Unit I has been further subdivided into seven subunits.

All the rocks of Unit I are macroscopically similar throughout the recovered sections. The upper part of Unit II appears autobrecciated, being constituted by angular fragments of basalts ( 1 to $5 \mathrm{~cm}$ across) healed together by a matrix made of glass and/or calcite, which decreases downward until the rock becomes massive at the interior pillow. Matrix composition indicates that fragmentation occurred both during cooling (fragments healed together by glassy material) and under subsolidus conditions (secondary minerals as calcite veining the glass).

All the recovered basaltic rocks are predominantly non- (or very scarcely) vesicular, generally hypocrystalline, fine- to medium-grained, aphyric to (olivine-) plagioclase-phyric.

Plagioclase phenocrysts dominate over olivine, this latter always occurring as microphenocrysts. Clinopyroxene and Fe-Ti oxides are confined to the groundmass. Textural relationships indicate that crystallization invariably took place in the following sequence: olivine, plagioclase, clinopyroxene, and $\mathrm{Fe}-\mathrm{Ti}$ oxides.

Primary textures are well preserved: they are mainly intersertal and intergranular, and, subordinately, subophitic to ophitic (Subunits $1 \mathrm{D}, 1 \mathrm{E}$, and $1 \mathrm{~F})$. In the least-crystallized rocks, the variably altered and/or recrystallized glassy mesostasis occupies the wedge-shaped interstices between the crystals. When patches of glass are sufficiently 


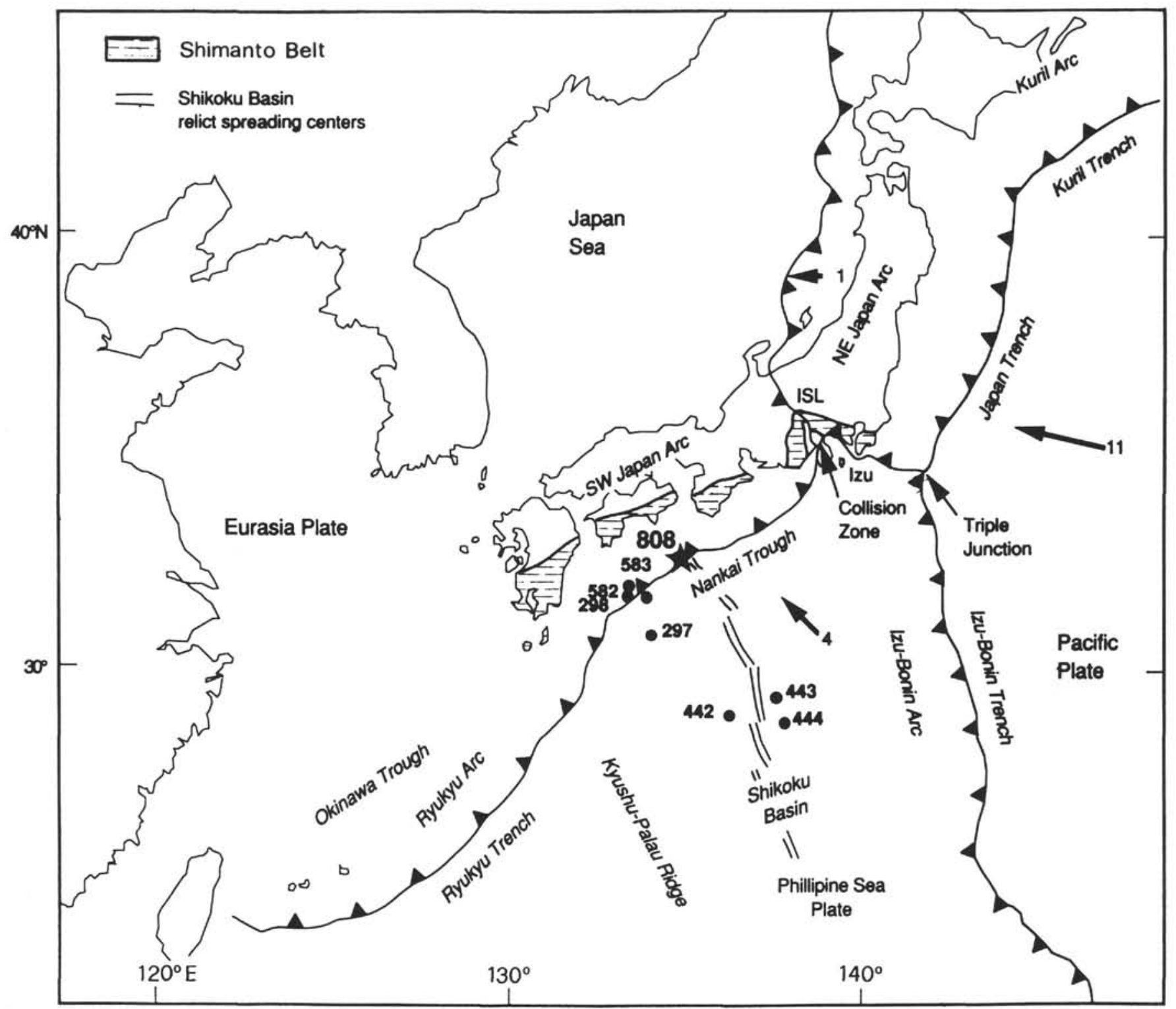

Figure 1. Tectonic setting of the Japanese arc-trench system, showing the location of major arc-trench systems, plate boundaries, and names of plates. Location of DSDP and ODP sites (dots) and the fossil spreading axis of the Shikoku Basin are also shown. Star indicates location of Site 808.

large and continuous to enclose a number of plagioclase and clinopyroxene laths, the texture becomes hyalopilitic. The basaltic angular fragments of the autobrecciated upper part of Unit II (pillow lava) are characterized by hyalopilitic, very fine-grained texture: tiny needlelike, often skeletal plagioclase microlites, radiating or branching, are embedded together with small mafic minerals in abundant, partly devitrified glassy mesostasis. The inner part of the pillow unit is more crystallized and shows textures analogous to those of basalts of Unit I.

The rare vesicles (up to $5 \%$, top of Unit II), generally concentrated in the upper parts of each subunit, are infilled with calcite, clay minerals, and minor zeolites (natrolite).

All the basaltic rocks of Site 808 suffered, to varying degrees, the effects of low-temperature seafloor alteration. The generally slight to moderate alteration was clearly controlled by fracturing, permeability, and solution-circulating pathways, together with crystallinity of the rocks, which may drastically reduce the rate of reaction between basalt and seawater, as studied experimentally by Seyfried and Bishoff (1977, 1979). Common alteration products are mixtures of $\mathrm{Fe}$-hydroxides and clay minerals, resulting in 0.5 to $1.5 \mathrm{~cm}$-wide reddish halos around cracks and veins. Prevailing alteration minerals are smectitic clays, which constitute the devitrification products of glassy mesostasis and glassy quench margins. Other secondary minerals include: serpentine, iddingsite, and chlorite (after olivine and, subordinately, clinopyroxene); calcite sometimes replacing mafic phases and, to a lesser extent, plagioclase; and albite + epidote after plagioclase (Sample 131-808C$106 \mathrm{R}-2,108-126 \mathrm{~cm})$. Whereas fresh olivine relics were found in only one sample (131-808C-107R-1, 0-8 cm), groundmass plagioclase and clinopyroxene are almost always unaltered.

All the recovered basaltic rocks are cut, to different degrees ( $0 \%$ to $10 \%$ ), by small, ramifying and often cross-cutting veins and fractures of varying width $(0.5-5.0 \mathrm{~mm})$. Their mutual relationships and the frequent multiple and zoned filling suggest several stages of fracturing and/or reopening and infilling. The thinnest veins are filled with mixed-layer clays, microcrystalline calcite, and rare zeolites; the medium-sized ones are generally filled with fibrous calcite. In the widest, often zoned veins, chlorite, and fibrous actinolite occur on the walls, and coarse-grained calcite occupies the inner part. Pyrite is a minor phase, sometimes present on the walls of cracks and veins. 


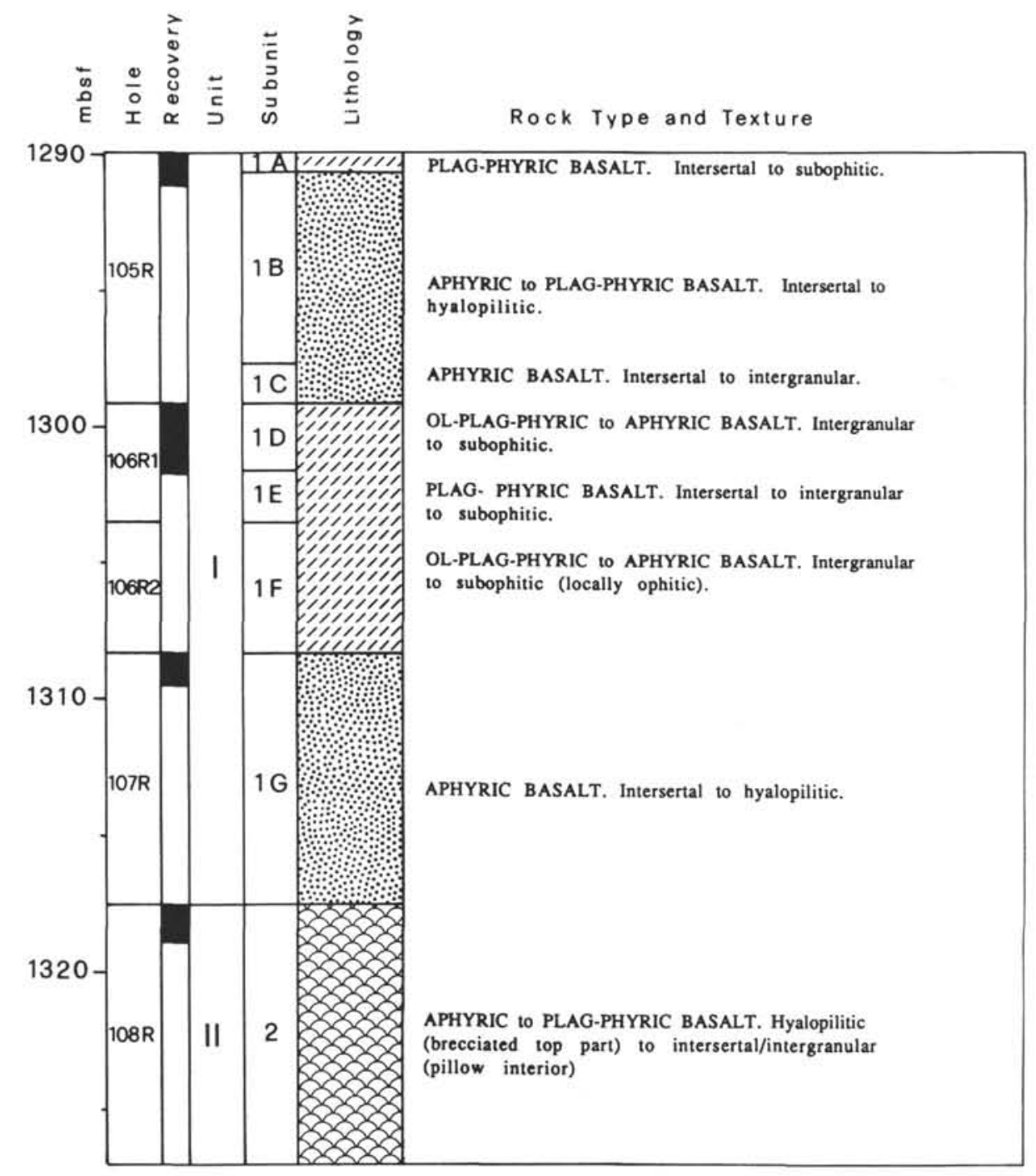

Figure 2. Lithostratigraphy, recovery, lithological units, and subunits of basement rocks, Site 808 .

Textural relationships suggest that calcite crystallization occurred in these rocks in several stages.

The main secondary assemblages are typical of low-temperature submarine alteration and early stages of low-grade metamorphism in the zeolite facies. Local development of the chlorite + albite + epidote association, together with actinolite as vein filling, are to be attributed to the lower part of greenschist facies (Elthon, 1981; Alt et al., 1986). Such secondary assemblages must be linked to the original hydrothermal system at the spreading axis because of the lack of veins in the accreted sediments overlying the basement basaltic rocks. A later extensive oxidation phase, related to downward percolation of oxygenated seawater, resulted in reddish halos with development of Fe-hydroxide phases.

\section{ANALYTICAL METHODS}

Minerals were analyzed at the University of Modena using an electron-probe microanalyzer with a SEMQ-ARL unit at an accelerating voltage of $15 \mathrm{kV}$, a specimen current of $5 \mathrm{nA}$, beam diameter of $2-3 \mu \mathrm{m}$, and counting time of $20 \mathrm{~s}$. Natural silicates and oxides were used as standards, and the raw data were corrected with the ZAF program using Bence and Albee (1968) factors.

X-ray fluorescence (XRF) analyses were performed on powder pellets using a wavelength-dispersive automated Philips PW 1400 spectrometer (Universities of Ferrara and Parma). Major elements were determined using a full matrix correction procedure (Franzini et al., 1975), whereas for trace elements, experimentally determined correction coefficients (Leoni and Saitta, 1976) were used. The precision and accuracy for trace-elements are estimated, for abundances greater than $10 \mathrm{ppm}$, to better than $7 \%$ (see analyses of reference standards AGV 1 and DR $\mathrm{N}$ in Table 4). $\mathrm{MgO}$ was analyzed in duplicate, with excellent agreement, by both atomic absorption and ICP, and loss on ignition (LOI) by the gravimetric method. REE were determined at the Centre de Recerches Pétrographiques et Géochimiques of Nancy (France), by inductively coupled plasma (ICP) emission spectrometry with accuracy of $15 \%$ for $\mathrm{Yb}$ and Lu and better than $8 \%$ for all the other REE (see analyses of reference standards from Roelandts and Michel, 1986).

$\mathrm{Sr}$ and $\mathrm{Nd}$ isotopic compositions were determined at the Istituto di Geocronologia e Geochimica Isotopica, CNR, Pisa, using a single collector Isomass 54E Spectrometer, following standard chemical methods. The reported errors are at the $95 \%$ confidence level.

\section{MINERAL CHEMISTRY}

Representative analyses of primary phases from Site 808 basaltic rocks are reported in Tables 1, 2, and 3. 
Fresh olivine was found as unzoned microphenocrysts in only one sample (131-808C-107R-1, 0-8 cm), with a forsterite content of $84 \%-85 \%$ (Table 1 and Fig. 3 ).

Clinopyroxenes are rather constant in composition, mostly plotting in the augite field (Fig. 3). In the discrimination diagram of Figure 4 (Beccaluva et al., 1989), they reveal a close affinity with clinopyroxenes of normal MORB. Some compositional variations (Table 2) can be observed in early to late crystallized clinopyroxenes; these consist of an increase of $\mathrm{TiO}_{2}$ and $\mathrm{FeO} / \mathrm{MgO}$ ratios, coupled with parallel decrease of $\mathrm{Cr}_{2} \mathrm{O}_{3}$, even in the same sample (e.g., Sample 131-808C-107R-1, 0-8 cm), and are due to fractional crystallization. However, anomalously high contents of both $\mathrm{TiO}_{2}$ and $\mathrm{Al}_{2} \mathrm{O}_{3}$ (Sample 131-808C-105R-1, 119-121 cm, and -106R-1, 17-22 cm) are most probably related to the influence of cooling rate in groundmass microlites (Beccaluva et al., 1989).

Plagioclase show a wide compositional range in both units (Table 3 and Fig. 3). Phenocrysts often show direct and/or oscillatory zoning. Anorthite contents range, on the whole, between $89.6 \%$ and $25.5 \%$ from phenocryst cores to rims to late crystallized groundmass microlites. Albitic plagioclases analyzed in samples from Section 131$808 \mathrm{C}-106 \mathrm{R}-2$ clearly represent secondary compositions. $\mathrm{K}_{2} \mathrm{O}$ content (mostly $<0.20 \mathrm{wt} \%$ ) is inversely correlated with anorthite content. The variation of $\mathrm{MgO}$ is typical of MORB plagioclase, showing the classic Mg drop at about $60 \%$ An (Perfit and Fornari, 1983).

$\mathrm{Fe}$-Ti oxides are rather uniform in composition (Table 1). They are Ti-magnetites with ulvospinel molecules varying from $57 \%$ to $69 \%$, within the range of those of MORB (Perfit and Fornari, 1983). Ilmenite was analyzed in only one sample (131-808C-106R-1, 80-83 cm).

\section{GEOCHEMISTRY}

Major and trace elements of representative samples of Units I and II are reported in Table 4, together with LOI, Mg numbers, and some significant incompatible element ratios.

All samples have suffered variable degrees of alteration due to rock/seawater interaction and very low-grade metamorphism, which is reflected by LOI values as high as $3.7 \mathrm{wt} \%$ in the least-crystalline rocks and the most altered pillow lavas. Chemical mobilization involved mostly alkalies (particularly $\mathrm{K}$ and $\mathrm{Rb}$ ) and, to a lesser extent, alkaline-earth elements. In particular, Samples 131-808C-108R-1, 63-66 cm, -108R-1, 118-121 cm, -108R-1, 122-127 cm, and -107R$1,104-128 \mathrm{~cm}$, show anomalously high $\mathrm{K}_{2} \mathrm{O}$ and $\mathrm{Rb}$ contents - and accordingly $\mathrm{K} / \mathrm{Nb}$ ratio-with respect to the others, which compare favorably with MORB compositions (see Saunders et al., 1988). MgO removal due to halmyrolysis may also be suspected for Samples 131-808C-105R-1, 8-19 cm, -108R-1, 63-66 cm, and -108R-1, 118$121 \mathrm{~cm}$, as suggested by their relatively high $\mathrm{Ni} / \mathrm{MgO}$ ratio (Table 4 ). High $\mathrm{CaO}$ content of the samples of Unit II seems to partially depend on the amount of calcite replacing primary phases and filling veins and vesicles. Therefore, pillow lavas from Unit II appear to have suffered the most intense secondary chemical mobilization, which is also reflected in the appearance of as much as $4.4 \%$ of nepheline in their norms.

Trace elements such as $\mathrm{Nb}, \mathrm{Y}, \mathrm{Zr}$, Ti, and REE, considered virtually immobile or very slightly mobile during seafloor weathering and lowgrade metamorphism (Hart et al., 1974; Bienvenu et al., 1990), have been used to assess the magmatic affinities of the Nankai basement rocks.

The MORB-normalized patterns of Figure 5 allow us a comprehensive view of incompatible element (plus chromium) distribution. Most elements delineate an almost flat pattern between one and three, further supporting the affinity of the studied rocks with MORB. The most scattered values are observed for $\mathrm{K}$ and $\mathrm{Rb}$, clearly in relation to secondary chemical mobilization. In terms of $\mathrm{Zr} / \mathrm{Y}$ vs. $\mathrm{Zr} / \mathrm{Nb}$ (Fig. 6 ), all the analyzed samples plot in the normal MORB field. Chondrite-normalized REE distributions (Fig. 7) show parallel patterns with significant LREE depletion $\left(\mathrm{La}_{N} / \mathrm{Sm}_{\mathrm{N}}=0.6-0.8\right)$. The overall REE abundance increases by about a factor of two, from the least to the most evolved basalts; in the latter a distinct Eu-negative anomaly appears in relation to plagioclase fractionation. The REE patterns, together with incompatible element ratios and clinopyroxene composition, confirm the close affinity with normal MORB type. It is to be noted that such a magmatism does not reveal any evidence of subduction-related geochemical components.

In terms of differentiation degree, the Nankai Trough basement rocks vary from nearly primitive $(\mathrm{Mg}: 71-67$; $\mathrm{Cr}: 270-222 \mathrm{ppm}$; Ni: $138-127 \mathrm{ppm}$ ) to rather evolved (Mg: 63-39) basalts. Rayleigh model calculations, based on several incompatible immobile elements such as $\mathrm{P}, \mathrm{Zr}, \mathrm{Nb}$, and $\mathrm{REE}$, suggest a maximum fractionation extent of about $40 \%$ of solid phases (olivine and plagioclase) from the least- to most-evolved rocks; this is also indicated by interelemental correlations and phenocryst nature.

The ${ }^{87} \mathrm{Sr} /{ }^{86} \mathrm{Sr}$ isotopic ratios (Table 4) range from 0.70339 in pillow lavas to 0.70317 in the least-altered basalt of the sill unit, whereas ${ }^{143} \mathrm{Nd} /{ }^{144} \mathrm{Nd}$ ratios are 0.51326 and 0.51314 , respectively. These values conform with those of slightly altered MORB, where strontium isotopic ratio has been variably increased by submarine alteration. Accordingly, ${ }^{87} \mathrm{Sr} /{ }^{86} \mathrm{Sr}$ ratios were reduced to $0.70265-$ 0.70271 by $\mathrm{HCl} 2.5 \mathrm{~N}$ hot leaching.

Stratigraphy, petrography, and geochemistry of basaltic rocks recovered at Site 808 appear very similar to those from the Shikoku Basin basement (particularly Sites 442 and 443, DSDP Leg 58 (Fig. 8); Nisterenko, 1980; Marsh et al., 1980), analogously identified as normal MORB.

\section{SUMMARY AND CONCLUSIONS}

1. The basaltic rocks at Site 808 were divided in two main units. Critical contacts confirming the mode of their emplacements were not recovered, yet available data suggest that Unit I consists of sill-like rocks and Unit II represents a pillow lava unit.

2. Both lithologic units are morphologically and petrographically similar to oceanic crust basalts: they were emplaced as sills and pillow lavas with textures typical of basalts erupted in a submarine environment. Both units are aphyric to (olivine-) plagioclase-phyric.

3. Alteration is generally slight to moderate. Secondary assemblages are dominated by smectitic clay, chlorite, serpentine, calcite, minor zeolite, and, locally, albite plus epidote. This is typical of submarine alteration and zeolite to low greenschist facies metamorphism. All of the recovered basaltic rocks are cut by ramifying and often cross-cutting veins of varying widths, infilled with calcite, chlorite, smectite, Fe-hydroxide, minor zeolite, and actinolite.

4. Geochemical features coherently indicate a normal MORB affinity for all the Nankai Trough basaltic rocks, without any evidence of subduction-related geochemical components. They vary from nearly primitive to rather evolved basaltic magmas, with an inferred maximum fractionation extent of about $40 \%$ of solid phases from the least to the most differentiated rocks.

5. Stratigraphic, petrographic, and geochemical features of the Nankai Trough basaltic rocks reveal a close analogy with those from Shikoku Basin basement, drilled during DSDP Leg 58, at Sites 442 and 443 near the fossil spreading axis.

\section{ACKNOWLEDGMENTS}

This work was financially supported by C.N.R. grant no. AI89.01952.05.

We thank L. Beccaluva for his scientific support and useful suggestions and Dr. A.D. Saunders for the thorough review of the manuscript. We also thank Dr. B. Galassi for cooperation in the analytical work. 


\section{REFERENCES}

Alt, J.C., Honnorez, J., Laverne, C., and Emmermann, R., 1986. Hydrothermal alteretion of a $1 \mathrm{~km}$ section through the upper oceanic crust, Deep Sea Drilling Project Hole 504B: mineralogy, chemistry and evolution of seawater-basalt interaction. J. Geophys. Res., 91:309-335.

Beccaluva, L., Macciotta, G., Piccardo, G.B., and Zeda, O., 1989. Clinopyroxene composition of ophiolite basalts as petrogenetic indicator. Chem. Geol., 77:165-182.

Bence, A., and Albee, A.L., 1968. Empirical correction factors for the electron microanalysis of silicates and oxides. J. Geol., 76:382-403.

Bienvenu, P., Bougault, H., Joron, J. L., Treuil, M., and Dimitriev, L., 1990. MORB alteration: rare-earth element/non-rare-earth hygromagmaphile element fractionation. Chem. Geol., 82:1-14.

Chamot-Rooke, N., Renard, V., and Le Pichon, X., 1987. Magnetic anomalies in the Shikoku Basin: a new interpretation. Earth Planet. Sci. Lett., 83:214-228.

Franzini, M., Leoni, L., and Saitta, M., 1975. Revisione di una metodologia analitica per fluorescenza di raggi $\mathrm{X}$ basata sulla correzione completa degli effetti di matrice. Rend. Soc. Ital. Mineral, Petrol., 31:365-378.

Elthon, D., 1981. Metamorphism in oceanic spreading centers. In Emiliani, C. (Ed.), The Sea (Vol. 7): The Oceanic Lithosphere: New York (Wiley), 285-303.

Hart, S. R., Erlank, A. J., and Kable, J. D., 1974. Sea floor basalt alteration: some chemical and Sr isotopic effects. Contrib. Mineral. Petrol., 44:219-230.

Kobayashi, K., and Nakada, M., 1978. Magnetic anomalies and tectonic evolution of the Shikoku inter-arc basin. J. Phys. Earth, 26:391-402.

Leoni, L., and Saitta, M., 1976. X-ray fluorescence analysis of 29 trace elements in rocks and mineral standards. Rend. Soc. Ital. Mineral. Petrol., $32: 479-510$

Le Roex, A. P., 1987. Source region of Mid-Ocean ridge basalts: evidence for enrichement processes. In Menzies, M.A., and Hawkesworth, C.J. (Eds.), Mantle Metasomatism: London (Academic Press), 389-419.

Marsh, N.G., Saunders, A.D., Tarney, J., and Dick, H.J.D., 1980. Geochemistry of basalts from the Shikoku and Daito Basins, Deep Sea Drilling Project Leg 58. In: Klein, G. deV., Kobayashi, K., et al., Init. Repts. DSDP, 58: Washington (U.S. Govt. Printing Office), 805-842.

Nisterenko, G.V., 1980. Petrochemistry and geochemistry of basalts in the Shikoku basin and Daito basin, Philippine Sea. In Klein, G. deV., and
Kobayashi, K., et al., Init. Repts. DSDP, 58: Washington (U.S. Govt. Printing Office), 791-804.

Papike, J.J., Cameron, K.L., and Baldwin, K., 1974. Amphiboles and pyroxenes: characterization of other than quadrilateral components and estimates of ferric iron from microprobe data. Geol. Soc. Am. Abstr. Programs, 6:1053-1054

Pearce, J.A., 1982. Trace element characteristics of lavas from destructive plate boundaries. In Thorpe, R.S. (Ed.), Andesites: New York (Wiley):525-548.

Perfit, M.R., and Fornari, D.J., 1983. Geochemical studies of abyssal lavas recovered by DSRV Alvin from eastern Galapagos Rift, Inca Transform, and Ecuador Rift. 2. Phase chemistry and crystallization history. J. Geophys. Res., 88:10530-10550.

Roelandts, I., and Michel, G., 1986. Sequential inductively coupled plasma determination of some rare-earth elements in five French geostandards. Geostand. Newsl., 10:135-154

Saunders, A.D., Norry, M.J., and Tarney, J., 1988. Origin of MORB and chemically depleted mantle reservoirs: trace element constraints. J. Petrol. (Spec. Lithospheric Iss.), 441-445.

Seyfried, W.E., and Bischoff, J.L., 1977. Hydrothermal transport of heavy metals by seawater: the role of seawater/basalt ratio. Earth Planet. Sci. Lett., 34:71-77.

, 1979. Low temperature basalt alteration by seawater: an experimental study at $70^{\circ} \mathrm{C}$ and $150^{\circ} \mathrm{C}$. Geochim. Cosmochim. Acta, 43:1937-1947.

Shih, T.C., 1980. Magnetic lineations in the Shikoku Basin. In Klein, G. deV., and Kobayashi, K., et al., Init. Repts. DSDP, 58: Washington (U.S. Govt. Printing Office), 783-788.

Shipboard Scientific Party, 1990. Site 808. In Taira, A., Hill, I.A., Firth, J. V., et al., Proc. ODP, Init. Repts., 131: College Station, TX (Ocean Drilling Program). 71-272.

Taylor, R.S., and Gorton, M.P., 1977. Geochemical application of spark source mass spectrography-III. Element sensitivity precision and accuracy. Geochim. Cosmochim. Acta, 41:1375-1380.

Date of initial receipt: 4 October 1991

Date of acceptance: 6 April 1992

Ms 131B-119 
Table 1. Representative microprobe analyses (wt \% oxide) and atomic proportions of olivine, Ti-magnetite, and ilmenite from Nankai Trough basement basaltic rocks in Hole $808 \mathrm{C}$.

\begin{tabular}{|c|c|c|c|c|c|c|c|c|c|c|c|c|c|c|}
\hline \multirow{4}{*}{$\begin{array}{l}\text { Core, section, } \\
\text { interval }(\mathrm{cm})\end{array}$} & \multicolumn{3}{|c|}{ Olivine } & \multicolumn{10}{|c|}{ Ti-Magnetite } & \multirow{4}{*}{ 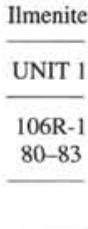 } \\
\hline & \multicolumn{11}{|c|}{ UNIT I } & \multirow{2}{*}{\multicolumn{2}{|c|}{$\begin{array}{c}\text { UNIT II } \\
108 \mathrm{R}-1 \\
122-127\end{array}$}} & \\
\hline & \multicolumn{3}{|c|}{$\begin{array}{c}107 \mathrm{R}-1 \\
0-8\end{array}$} & $\begin{array}{c}105 R-1 \\
119-121\end{array}$ & $\begin{array}{c}106 \mathrm{R}-1 \\
17-22\end{array}$ & \multicolumn{2}{|c|}{$\begin{array}{c}106 \mathrm{R}-2 \\
51-54\end{array}$} & \multicolumn{2}{|c|}{$\begin{array}{c}106 R-2 \\
108-126\end{array}$} & \multicolumn{2}{|c|}{$\begin{array}{c}107 R-1 \\
0-8\end{array}$} & & & \\
\hline & A & B & C & & & A & B & A & B & A & B & A & B & \\
\hline $\mathrm{SiO}_{2}$ & 40.84 & 40.47 & 40.19 & 0.65 & 0.34 & 0.89 & 1.61 & 0.21 & 0.00 & 0.17 & 1.21 & 0.24 & 0.45 & 0.15 \\
\hline $\mathrm{TiO}_{2}$ & 0.00 & 0.03 & 0.00 & 25.03 & 23.70 & 24.75 & 23.01 & 22.30 & 25.58 & 22.29 & 22.17 & 22.35 & 21.25 & 47.18 \\
\hline $\mathrm{Al}_{2} \mathrm{O}_{3}$ & 0.37 & 0.00 & 0.00 & 2.18 & 1.21 & 2.04 & 1.75 & 1.31 & 0.53 & 1.55 & 1.65 & 2.78 & 3.32 & 0.36 \\
\hline $\mathrm{Fe}_{2} \mathrm{O}_{3}$ & & & & 15.88 & 21.77 & 16.65 & 19.54 & 25.34 & 19.44 & 24.80 & 22.24 & 21.11 & 22.46 & 9.60 \\
\hline $\mathrm{FeO}$ & 14.86 & 13.67 & 14.57 & 51.29 & 48.47 & 53.71 & 50.69 & 49.28 & 51.74 & 48.82 & 50.76 & 50.40 & 49.37 & 37.17 \\
\hline $\mathrm{MnO}$ & 0.00 & 0.26 & 0.18 & 2.82 & 2.93 & 1.76 & 1.55 & 3.02 & 3.34 & 0.82 & 1.40 & 1.74 & 2.19 & 3.20 \\
\hline $\mathrm{MgO}$ & 43.15 & 44.93 & 44.46 & 0.41 & 0.00 & 0.00 & 1.58 & 0.31 & 0.00 & 1.72 & 0.96 & 0.00 & 0.00 & 0.25 \\
\hline $\mathrm{CaO}$ & 0.36 & 0.35 & 0.36 & 0.29 & 0.12 & 0.06 & 0.14 & 0.03 & 0.00 & 0.02 & 0.04 & 0.10 & 0.12 & 0.16 \\
\hline $\mathrm{Cr}_{2} \mathrm{O}_{3}$ & 0.00 & 0.00 & 0.00 & 0.00 & 0.00 & 0.00 & 0.00 & 0.00 & 0.00 & 0.00 & 0.00 & 0.13 & 0.00 & 0.00 \\
\hline $\mathrm{NiO}$ & 0.19 & 0.12 & 0.14 & 0.00 & 0.00 & 0.00 & 0.00 & 0.00 & 0.00 & 0.00 & 0.00 & 0.00 & 0.00 & 0.88 \\
\hline Tot & 99.77 & 99.83 & 99.9 & 98.55 & 98.54 & 99.86 & 99.87 & 101.8 & 100.63 & 100.19 & 100.43 & 98.85 & 99.16 & 98.95 \\
\hline $\mathrm{Si}$ & 1.024 & 1.005 & 1.008 & 0.024 & 0.013 & 0.033 & 0.059 & 0.008 & 0.000 & 0.006 & 0.044 & 0.009 & 0.017 & 0.004 \\
\hline $\mathrm{Ti}$ & 0.000 & 0.001 & 0.000 & 0.704 & 0.669 & 0.690 & 0.634 & 0.615 & 0.716 & 0.617 & 0.612 & 0.630 & 0.595 & 0.906 \\
\hline $\mathrm{Al}$ & 0.011 & 0.000 & 0.000 & 0.096 & 0.054 & 0.089 & 0.076 & 0.057 & 0.023 & 0.067 & 0.071 & 0.123 & 0.146 & 0.011 \\
\hline $\mathrm{Fe}^{3+}$ & & & & 0.450 & 0.610 & 0.460 & 0.540 & 0.700 & 0.540 & 0.690 & 0.610 & 0.600 & 0.630 & 0.170 \\
\hline $\mathrm{Fe}^{2+}$ & 0.311 & 0.284 & 0.306 & 1.600 & 1.520 & 1.670 & 1.550 & 1.510 & 1.610 & 1.500 & 1.560 & 1.580 & 1.540 & 0.809 \\
\hline $\mathrm{Mn}$ & 0.000 & 0.005 & 0.004 & 0.089 & 0.093 & 0.055 & 0.048 & 0.094 & 0.105 & 0.026 & 0.044 & 0.055 & 0.069 & 0.069 \\
\hline $\mathrm{Mg}$ & 1.612 & 1.663 & 1.662 & 0.023 & 0.000 & 0.000 & 0.086 & 0.017 & 0.000 & 0.094 & 0.053 & 0.000 & 0.000 & 0.010 \\
\hline $\mathrm{Ca}$ & 0.010 & 0.009 & 0.010 & 0.012 & 0.005 & 0.002 & 0.005 & 0.001 & 0.000 & 0.001 & 0.002 & 0.004 & 0.005 & 0.004 \\
\hline $\mathrm{Cr}$ & 0.000 & 0.000 & 0.000 & 0.000 & 0.000 & 0.000 & 0.000 & 0.000 & 0.000 & 0.000 & 0.000 & 0.004 & 0.000 & 0.000 \\
\hline $\mathrm{Ni}$ & 0.004 & 0.002 & 0.003 & 0.000 & 0.000 & 0.000 & 0.000 & 0.000 & 0.000 & 0.000 & 0.000 & 0.000 & 0.000 & 0.018 \\
\hline Fo & 83.8 & 85.4 & 84.5 & & & & & & & & & & & \\
\hline Ulv & & & & 66.2 & 62.3 & 68.6 & 60.6 & 56.7 & 66.7 & 57.4 & 62.2 & 60.7 & 57.0 & \\
\hline
\end{tabular}

Note: $\mathrm{Fe}^{3+} / \mathrm{Fe}^{2+}$ partitioning according to charge balance. $\mathrm{A}, \mathrm{B}$, and $\mathrm{C}$ refer to different crystals. Forsterite ( $\mathrm{Fo}$ ) and ulvospinel (Ulv) percentages are in atom\%.

Table 2. Representative microprobe analyses (wt \% oxide) and atomic proportions of clinopyroxene from Nankai Trough basement basaltic rocks in Hole $808 \mathrm{C}$.

\begin{tabular}{|c|c|c|c|c|c|c|c|c|c|c|c|c|c|c|}
\hline \multirow{3}{*}{$\begin{array}{l}\text { Core, section, } \\
\text { interval }(\mathrm{cm})\end{array}$} & \multicolumn{12}{|c|}{ UNIT I } & \multirow{2}{*}{\multicolumn{2}{|c|}{$\begin{array}{c}\text { UNIT II } \\
108 \mathrm{R}-1 \\
122-127\end{array}$}} \\
\hline & \multicolumn{2}{|c|}{$\begin{array}{c}105 R-1 \\
119-121\end{array}$} & \multicolumn{2}{|c|}{$\begin{array}{c}106 \mathrm{R}-1 \\
17-22\end{array}$} & \multicolumn{2}{|c|}{$\begin{array}{c}106 \mathrm{R}-1 \\
80-83\end{array}$} & \multicolumn{2}{|c|}{$\begin{array}{c}106 R-2 \\
51-54\end{array}$} & \multirow{2}{*}{$\frac{\begin{array}{c}106 \mathrm{R}-2 \\
108-126\end{array}}{\mathrm{~A}}$} & \multicolumn{2}{|c|}{$\begin{array}{c}107 R-1 \\
00-08\end{array}$} & \multirow{2}{*}{$\frac{\begin{array}{c}107 R-1 \\
63-65\end{array}}{A}$} & & \\
\hline & A & B & A & B & A & B & A & B & & A & B & & A & B \\
\hline $\mathrm{SiO}_{2}$ & 44.09 & 46.71 & 47.88 & 46.01 & 48.60 & 49.45 & 46.95 & 48.36 & 47.47 & 49.46 & 46.43 & 48.21 & 47.85 & 47.51 \\
\hline $\mathrm{TiO}_{2}^{2}$ & 2.77 & 2.02 & 1.82 & 2.70 & 1.85 & 1.46 & 2.31 & 2.08 & 1.95 & 1.65 & 3.47 & 2.36 & 1.83 & 2.15 \\
\hline $\mathrm{Al}_{2} \mathrm{O}_{3}$ & 6.22 & 5.35 & 4.06 & 6.96 & 4.64 & 3.56 & 4.90 & 5.60 & 4.57 & 3.76 & 4.16 & 5.53 & 4.98 & 4.80 \\
\hline $\mathrm{Fe}_{2} \mathrm{O}_{3}$ & 2.57 & 2.27 & 1.99 & 1.47 & 1.11 & 1.36 & 1.76 & 1.00 & 1.99 & 0.17 & 1.13 & 0.26 & 1.69 & 1.47 \\
\hline $\mathrm{FeO}$ & 7.11 & 7.02 & 10.31 & 6.90 & 8.35 & 8.50 & 10.52 & 7.09 & 6.79 & 8.16 & 11.83 & 11.30 & 7.50 & 7.74 \\
\hline $\mathrm{MnO}$ & 0.17 & 0.24 & 0.29 & 0.21 & 0.18 & 0.29 & 0.31 & 0.15 & 0.18 & 0.15 & 0.32 & 0.36 & 0.23 & 0.96 \\
\hline $\mathrm{MgO}$ & 12.28 & 12.70 & 11.82 & 13.63 & 12.82 & 13.76 & 12.81 & 13.33 & 14.14 & 14.00 & 11.96 & 13.43 & 13.56 & 13.59 \\
\hline $\mathrm{CaO}$ & 22.43 & 22.99 & 20.92 & 22.24 & 21.75 & 20.84 & 19.70 & 21.53 & 21.46 & 21.56 & 20.29 & 17.84 & 21.80 & 21.37 \\
\hline $\mathrm{Na}_{2} \mathrm{O}$ & 0.35 & 0.46 & 0.81 & 0.00 & 0.51 & 0.58 & 0.49 & 0.60 & 0.47 & 0.00 & 0.23 & 0.37 & 0.40 & 0.19 \\
\hline $\mathrm{K}_{2} \mathrm{O}$ & 0.00 & 0.00 & 0.00 & 0.00 & 0.00 & 0.00 & 0.00 & 0.00 & 0.00 & 0.00 & 0.00 & 0.00 & 0.00 & 0.00 \\
\hline $\mathrm{Cr}_{2} \mathrm{O}_{3}$ & 0.25 & 0.00 & 0.00 & 0.48 & 0.23 & 0.00 & 0.00 & 0.23 & 0.31 & 0.09 & 0.00 & 0.11 & 0.15 & 0.17 \\
\hline Tot & 98.24 & 99.76 & 99.90 & 100.60 & 100.04 & 99.80 & 99.75 & 99.97 & 99.33 & 99.00 & 99.82 & 99.77 & 99.99 & 99.95 \\
\hline Si & 1.712 & 1.775 & 1.830 & 1.723 & 1.829 & 1.863 & 1.792 & 1.809 & 1.799 & 1.864 & 1.782 & 1.816 & 1.803 & 1.795 \\
\hline $\mathrm{Ti}$ & 0.081 & 0.058 & 0.052 & 0.076 & 0.052 & 0.041 & 0.066 & 0.059 & 0.056 & 0.047 & 0.100 & 0.067 & 0.052 & 0.061 \\
\hline $\mathrm{Al}$ & 0.285 & 0.240 & 0.183 & 0.307 & 0.206 & 0.158 & 0.220 & 0.247 & 0.204 & 0.167 & 0.188 & 0.245 & 0.221 & 0.214 \\
\hline $\mathrm{Fe}^{3+}$ & 0.075 & 0.065 & 0.057 & 0.041 & 0.031 & 0.038 & 0.051 & 0.028 & 0.057 & 0.005 & 0.033 & 0.007 & 0.048 & 0.042 \\
\hline $\mathrm{Fe}^{2+}$ & 0.231 & 0.223 & 0.330 & 0.216 & 0.263 & 0.268 & 0.336 & 0.222 & 0.215 & 0.257 & 0.380 & 0.356 & 0.236 & 0.245 \\
\hline Mn & 0.006 & 0.008 & 0.009 & 0.007 & 0.006 & 0.009 & 0.010 & 0.005 & 0.006 & 0.005 & 0.010 & 0.011 & 0.007 & 0.031 \\
\hline $\mathrm{Mg}$ & 0.711 & 0.719 & 0.673 & 0.761 & 0.719 & 0.773 & 0.729 & 0.743 & 0.799 & 0.786 & 0.684 & 0.754 & 0.761 & 0.765 \\
\hline $\mathrm{Ca}$ & 0.933 & 0.936 & 0.857 & 0.892 & 0.877 & 0.841 & 0.805 & 0.863 & 0.871 & 0.871 & 0.834 & 0.720 & 0.880 & 0.865 \\
\hline $\mathrm{Na}$ & 0.026 & 0.034 & 0.060 & 0.000 & 0.037 & 0.042 & 0.036 & 0.044 & 0.035 & 0.000 & 0.017 & 0.027 & 0.029 & 0.014 \\
\hline K & 0.000 & 0.000 & 0.000 & 0.000 & 0.000 & 0.000 & 0.000 & 0.000 & 0.000 & 0.000 & 0.000 & 0.000 & 0.000 & 0.000 \\
\hline $\mathrm{Cr}$ & 0.008 & 0.000 & 0.000 & 0.014 & 0.007 & 0.000 & 0.000 & 0.007 & 0.009 & 0.003 & 0.000 & 0.003 & 0.004 & 0.005 \\
\hline $\mathrm{mg}$ & 75.5 & 76.3 & 67.1 & 77.9 & 73.2 & 74.3 & 68.5 & 77.0 & 78.8 & 75.4 & 64.3 & 67.9 & 76.3 & 75.7 \\
\hline
\end{tabular}

Note: $\mathrm{Fe}^{3+} / \mathrm{Fe}^{2+}$ partitioning according to Papike et al., 1974. $\mathrm{mg}=\left(\mathrm{Mg} / \mathrm{Mg}+\mathrm{Fe}^{2+}\right)$ (atom\%). $\mathrm{A}$ and $\mathrm{B}$ refer to different crystals. 
Table 3. Representative microprobe analyses (wt \% oxide) and atomic proportions of plagioclase from Nankai Trough basement basaltic rocks in Hole 808C.

\begin{tabular}{|c|c|c|c|c|c|c|c|c|c|c|c|c|c|c|c|c|}
\hline \multirow{3}{*}{$\begin{array}{l}\text { Core, section, } \\
\text { interval }(\mathrm{cm})\end{array}$} & \multicolumn{16}{|c|}{ UNIT I } \\
\hline & \multicolumn{3}{|c|}{$\begin{array}{l}105 R-1 \\
20-26\end{array}$} & \multicolumn{3}{|c|}{$\begin{array}{l}105 R-1 \\
119-121\end{array}$} & \multicolumn{4}{|c|}{$\begin{array}{l}106 R-1 \\
17-22\end{array}$} & \multicolumn{5}{|c|}{$\begin{array}{l}106 R-1 \\
80-83\end{array}$} & \multirow{2}{*}{$\frac{\begin{array}{c}106 \mathrm{R}-2 \\
51-54\end{array}}{\mathrm{Ar}}$} \\
\hline & Ac & Ar & $\mathrm{Bgr}$ & Ac & Ar & Bgr & $A c$ & Ar & Bgr & $\mathrm{Cgr}$ & Ac & Ar & Bgr & Cgr & $A C$ & \\
\hline $\mathrm{SiO}_{2}$ & 48.00 & 49.41 & 51.42 & 49.26 & 50.53 & 49.22 & 50.90 & 50.08 & $52 .+3$ & 50.13 & 49.65 & 50.38 & 51.77 & 62.16 & 50.48 & 59.14 \\
\hline $\mathrm{TiO}_{2}$ & 0.07 & 0.06 & 0.12 & 0.04 & 0.0 .3 & 0.08 & 0.06 & 0.05 & 0.12 & 0.06 & 0.06 & 0.05 & 0.07 & 0.10 & 0.07 & 0.15 \\
\hline $\mathrm{Al}_{2} \mathrm{O}_{3}$ & 30.86 & 30.60 & 29.06 & 31.92 & 29.96 & 31.43 & 30.79 & 30.84 & 26.94 & $30 .+6$ & 31.47 & 30.75 & 29.74 & 23.75 & 29.68 & 25.60 \\
\hline $\mathrm{Fe}_{2} \mathrm{O}_{3}$ & 0.46 & 0.68 & 0.98 & 0.46 & 1.00 & 0.48 & 0.51 & 0.63 & 1.14 & 0.73 & 0.44 & 0.47 & 0.81 & 0.46 & 1.63 & 0,78 \\
\hline $\mathrm{MnO}$ & 0.00 & 0.00 & 0.00 & 0.00 & 0.00 & 0.00 & 0.00 & $0 .(0)$ & 0.00 & 0.00 & 0.00 & 0.00 & $0.06)$ & 0.00 & 0.00 & 0.00 \\
\hline $\mathrm{MgO}$ & 0.41 & 0.53 & 0.22 & 0.00 & 0.83 & 0.00 & 0.32 & 0.22 & 0.00 & 0.19 & 0.29 & 0.26 & 0.00 & 0.00 & 1.44 & 0,00 \\
\hline $\mathrm{CaO}$ & 14.58 & 14.50 & 12.78 & 15.36 & 13.73 & 14.85 & 13.58 & 13.97 & 10.37 & 13.54 & 15.14 & 14.74 & $13.00)$ & 5.30 & 13.26 & 7.90 \\
\hline $\mathrm{Na}_{2} \mathrm{O}$ & 3.28 & 3.74 & 5.12 & 3,00 & 4.06 & 4.00 & 3.75 & 4.29 & 6.06 & 4,42 & 2.80 & 3.20 & $3.8,3$ & 8.46 & 3.05 & 6.76 \\
\hline $\mathrm{K}_{2} \mathrm{O}$ & 0.11 & 0.00 & 0.02 & 0.00 & 0.02 & 0.02 & 0.00 & 0.02 & 0.10 & 0.02 & $0.00)$ & 0.00 & 0.05 & 0.15 & 0.06 & 0.09 \\
\hline Total & 97.77 & 99.52 & 99.72 & 100.04 & 100.16 & 100.08 & 99.91 & 100.10 & 97.16 & 99.55 & 99.85 & 99.8 .5 & 99.27 & 1000.38 & 99.67 & 100.42 \\
\hline $\mathrm{Si}$ & 2.198 & 2.278 & 2.36 .3 & 2.256 & 2.307 & 2.2 .37 & 2.322 & 2.294 & 2.398 & 2.307 & 2.274 & 2.306 & 2.368 & 2.752 & 2.313 & 2.637 \\
\hline$\pi i$ & 0.002 & 0.002 & 0.004 & 0.001 & $0 .(0) 1$ & 0.003 & $0.0 \times 12$ & 0.002 & 0.004 & 0.002 & 0.0012 & $0.00) 2$ & $0 .(0) 2$ & 0.00 .3 & 0.002 & 0.005 \\
\hline $\mathrm{Al}$ & 1.666 & 1.663 & 1.574 & 1.723 & 1.61 .3 & 1.684 & 1.666 & 1.66 .5 & 1.452 & 1.652 & 1.699 & 1.659 & 1.604 & 1.239 & 1.603 & 1.346 \\
\hline $\mathrm{Fe}^{3+}$ & 0.018 & 0.026 & 0.037 & 0.018 & 0.0 .37 & 0.018 & 0.020 & 0.024 & 0.043 & 0.028 & 0.017 & 0.018 & 0.031 & 0.017 & 0.062 & 0.029 \\
\hline $\mathrm{Mn}$ & 0.000 & 0.000 & 0.000 & 0.000 & 0.000 & $0.000)$ & $0.0(06)$ & 0.0000 & $0.000)$ & 0.0000 & $0.000)$ & 0.0000 & $0.000)$ & 0.000 & 0.000 & 0.000 \\
\hline $\mathrm{Mg}$ & 0.028 & 0.036 & 0.015 & 0.000 & 0.056 & 0.0000 & 0.022 & 0.015 & $0.000)$ & 0.013 & 0.020 & 0.018 & $0.0(X)$ & $0.00(x)$ & 0.0998 & 0.000 \\
\hline $\mathrm{Ca}$ & 0.715 & 0.716 & 0.629 & 0.754 & 0.672 & 0.723 & 0.664 & 0.686 & $0.50 \mathrm{~K}$ & 0.668 & 0.743 & 0.723 & 0.6 .37 & 0.251 & 0.651 & 0.377 \\
\hline $\mathrm{Na}$ & 0.291 & 0.334 & 0.456 & 0.266 & 0.359 & 0.352 & 0.332 & 0.381 & 0.537 & 0.394 & 0.249 & 0.284 & 0.340 & 0.726 & 0.271 & 0.584 \\
\hline K & 0.006 & 0.000 & 0.001 & 0.900 & $0 .(0) 1$ & $0 .(x) \mid$ & $0.006)$ & $0 .(0) 1$ & 0.006 & 0.001 & $0.000)$ & $0.0(0)$ & $0 .(0) 3$ & 0.008 & 0.004 & 0.005 \\
\hline An & 70.7 & 68.2 & 57.9 & 73.9 & 65.1 & 67.2 & 66.7 & 64.2 & 48.3 & 62.8 & 74.9 & 71.8 & 65.0 & 25.5 & 70.3 & 39.0 \\
\hline
\end{tabular}

Table 3 (continued).

\begin{tabular}{|c|c|c|c|c|c|c|c|c|c|c|c|c|c|c|}
\hline \multirow{3}{*}{$\begin{array}{l}\text { Core, section, } \\
\text { interval }(\mathrm{cm})\end{array}$} & \multicolumn{8}{|c|}{ UNIT 1} & \multicolumn{6}{|c|}{ UNIT II } \\
\hline & \multicolumn{3}{|c|}{$\begin{array}{c}106 \mathrm{R}-2 \\
108-126\end{array}$} & \multicolumn{3}{|c|}{$\begin{array}{c}107 R-1 \\
0-8\end{array}$} & \multicolumn{2}{|c|}{$\begin{array}{l}107 R-1 \\
63-65\end{array}$} & \multicolumn{3}{|c|}{$\begin{array}{l}108 \mathrm{R}-1 \\
89-94\end{array}$} & \multicolumn{3}{|c|}{$\begin{array}{l}\text { 108R-1 } \\
122-127\end{array}$} \\
\hline & $\mathrm{Bgr}$ & A & B & Ac & At & B & A & B & $\mathrm{Ac}$ & Ar & $\mathrm{Bgr}$ & Ac & $\mathrm{Ar}$ & B \\
\hline $\mathrm{SiO}_{2}$ & 54.19 & 51.69 & 65.52 & 50.83 & $\$ 3.25$ & 49.21 & 52.72 & 53.46 & 53.00 & 52.69 & 60.25 & 52.45 & 57.20 & 66.74 \\
\hline $\mathrm{TiO}_{2}^{-}$ & 0.06 & 0.05 & 0.30 & 0.00 & 0.35 & 0.04 & 0.08 & 0.06 & 0.10 & 0.09 & 0.16 & 0.08 & 0.10 & 0.12 \\
\hline $\mathrm{Al}_{2} \mathrm{O}_{3}$ & 28.49 & 30.26 & 21.85 & 30.91 & 29.08 & 31.50 & 29.51 & 29.18 & 29.27 & 30.55 & 25.58 & 30.26 & 27.66 & 27.97 \\
\hline $\mathrm{Fe}_{2} \mathrm{O}_{3}$ & 0.74 & 0.74 & 1.32 & 0.40 & 1.99 & 0.64 & 0.96 & 0.91 & 1.00 & 0.52 & 1.03 & 0.38 & 0.77 & 0.98 \\
\hline $\mathrm{MnO}$ & 0.00 & 0.00 & 0.00 & 0.00 & 0.00 & 0.00 & 0.00 & 0.00 & 0.00 & 0.00 & 0.00 & 0.00 & 0.00 & 0.00 \\
\hline $\mathrm{MgO}$ & 0.00 & 0.00 & 0.19 & 0.23 & 0.00 & 0.38 & 0.48 & 0.37 & 0.28 & 0.27 & 0.00 & 0.21 & 0.00 & 0.00 \\
\hline $\mathrm{CaO}$ & 11.64 & 13.56 & 0.67 & 16.15 & 13.40 & 16.99 & 14.37 & 13.70 & 14.30 & 13.91 & 8.52 & 14.50 & 10.70 & 11.02 \\
\hline $\mathrm{Na}_{2} \mathrm{O}$ & 4.78 & 3.65 & 9.63 & 1.31 & 1.97 & 1.09 & 1.64 & 2.03 & 1.92 & 1.84 & 4.05 & 2.02 & 3.11 & 3.02 \\
\hline $\mathrm{K}_{2} \mathrm{O}$ & 0.04 & 0.02 & 0.86 & 0.00 & 0.03 & 0.00 & 0.07 & 0.05 & 0.04 & 0.02 & 0.13 & 0.00 & 0.07 & 0.07 \\
\hline Total & 99.94 & 99.97 & 100.34 & 99.83 & 100.07 & 99.85 & 99.83 & 99.86 & 99.91 & 99.89 & 99.72 & 99.90 & 99.61 & 99.92 \\
\hline $\mathrm{Si}$ & 2.456 & 2.356 & 2.880 & 2.317 & 2.418 & 2.257 & 2.394 & 2.421 & 2.406 & 2.382 & 2.680 & 2.376 & 2.563 & 2.542 \\
\hline $\mathrm{Ti}$ & 0.002 & 0.002 & 0.010 & 0.000 & 0.012 & 0.001 & 0.003 & 0.002 & 0.003 & 0.003 & 0.005 & 0.003 & 0.003 & 0.004 \\
\hline Al & 1.522 & 1.626 & 1. 132 & 1.661 & 1.556 & 1.703 & 1.580 & 1.563 & 1.566 & 1.628 & 1.341 & 1.616 & 1.461 & 1.477 \\
\hline $\mathrm{Fe}^{3+}$ & 0.028 & 0.029 & 0.048 & 0.015 & 0.076 & 0.024 & 0.036 & 0.034 & 0.037 & 0.020 & 0.039 & 0.014 & 0.029 & 0.036 \\
\hline $\mathrm{Mn}$ & 0.000 & 0.000 & 0.000 & 0.000 & 0.000 & 0.000 & 0.000 & 0.000 & 0.000 & 0.000 & 0.000 & 0.000 & 0.000 & 0.000 \\
\hline $\mathrm{Mg}$ & 0.000 & 0.000 & 0.012 & 0.016 & 0.000 & 0.026 & 0.032 & 0.025 & 0.019 & 0.018 & 0.000 & 0.014 & 0.000 & 0.000 \\
\hline $\mathrm{Ca}$ & 0.565 & 0.662 & 0.032 & 0.789 & 0.652 & 0.835 & 0.699 & 0.665 & 0.695 & 0.674 & 0.406 & 0.704 & 0.514 & 0.529 \\
\hline $\mathrm{Na}$ & 0.420 & 0.323 & 0.821 & 0.116 & 0.173 & 0.097 & 0.144 & 0.178 & 0.169 & 0.161 & 0.349 & 0.177 & 0.270 & 0.262 \\
\hline K & 0.002 & 0.001 & 0.048 & 0.000 & 0.002 & 0.000 & 0.004 & 0.003 & 0.002 & 0.001 & 0.007 & 0.000 & 0.004 & 0.004 \\
\hline An & 57.2 & 67.1 & 3.6 & 87.2 & 78.8 & 89.6 & 82.5 & 78.6 & 80.3 & 80.6 & 53.3 & 79.9 & 65.2 & 66.5 \\
\hline
\end{tabular}

Note: Abbreviations: c, crystal core; r, crystal rim; gr, crystal in groundmass. A, B, and C refer to different crystals. 

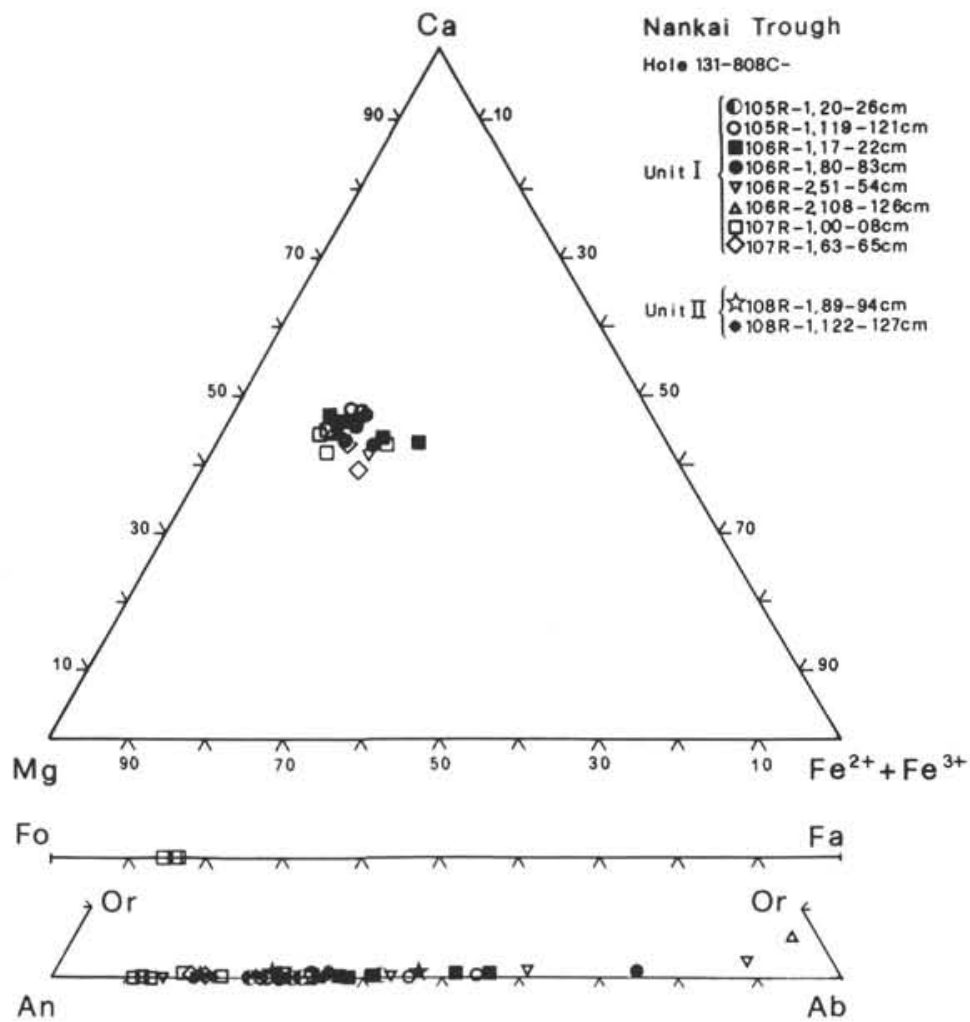

Figure 3. Clinopyroxene, olivine, and plagioclase composition of the Nankai Trough basalts in the $\mathrm{Ca}-\mathrm{Mg}-\mathrm{Fe}$ (atom\%) diagram, in terms of forsterite-fayalite percentages, and in the Ab-An-Or (mole\%) diagram, respectively.

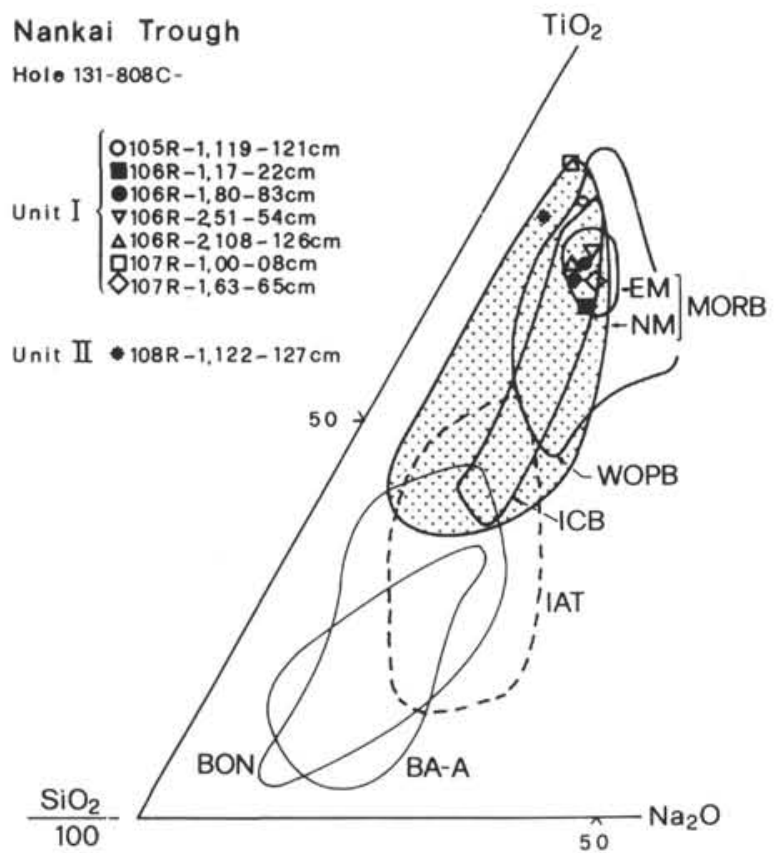

Figure 4. Clinopyroxene compositions of Nankai Trough basement rocks in the $\mathrm{TiO}_{2}-\mathrm{Na}_{2} \mathrm{O}-\mathrm{SiO}_{2} / 100$ diagram (wt \%). The discrimination fields for clinopyroxene from basalts of different oceanic settings are reported (after Beccaluva et al., 1989). Abbreviations: normal (NM) and enriched (EM) MORB; within oceanic plate basalts (WOPB); Iceland basalts (ICB); Island arc tholeiites (IAT); Boninites (BON); Quartz-tholeiites, basaltic andesites, and andesites (BA-A) from intraoceanic forearc regions. Symbols indicate representative analyses. 
Table 4. Representative major- (wt \%) and trace- (ppm) element analyses, and ${ }^{87} \mathrm{Sr} /{ }^{86} \mathrm{Sr}$ and ${ }^{143} \mathrm{Nd} /{ }^{144} \mathrm{Nd}$ ratios of basaltic rocks from Nankai Trough basement in Hole $808 \mathrm{C}$.

\begin{tabular}{|c|c|c|c|c|c|c|c|c|c|c|c|c|c|c|c|c|c|c|c|c|c|}
\hline \multirow{3}{*}{$\begin{array}{l}\text { Core, section. } \\
\text { Interval }(\mathrm{cm})\end{array}$} & \multicolumn{14}{|c|}{ UNIT I } & \multicolumn{3}{|c|}{ UNIT II } & & & \multirow{3}{*}{\multicolumn{2}{|c|}{$\begin{array}{l}\text { DR N } \\
\mathrm{A}(\mathrm{XRF})\end{array}$}} \\
\hline & $105 R-1$ & $\begin{array}{l}\text { 105R-I } \\
20-26\end{array}$ & 105R-1 & $106 \mathrm{R}-1$ & 106R-1 & 106R-I & 106R-1 & 106R-2 & 106R-2 & 106R-2 & 107R-1 & 107R-1 & 107R-1 & 107R-1 & 108R-1 & 108R-1 & 108R-1 & \multicolumn{2}{|c|}{ AGV I } & & \\
\hline & & & & & & & $122-125$ & $17-22$ & & $60-64$ & & $28-31$ & 63-65 & $104-128$ & $63-66$ & $118-121$ & $122-127$ & $A(X R F)$ & B & & \\
\hline $\mathrm{SiO}_{2}$ & 48.06 & 49.16 & 50.08 & 47.81 & 48.86 & 49.10 & 47.87 & 47.60 & 47.38 & 47.29 & 46.67 & 47.57 & 49.09 & 47.21 & 45.61 & 47.05 & 48.59 & 59.13 & 59.29 & 52.14 & 52.8 \\
\hline $\mathrm{TiO}_{2}$ & 1.60 & 1.71 & 1.70 & 1.56 & 1.58 & 1.66 & 1.57 & 1.60 & 1.55 & 1.31 & 1.29 & 1.66 & 1.80 & 1.83 & 2.15 & 2.00 & 2.08 & 1.09 & 1.05 & 1.19 & 1.0 \\
\hline $\mathrm{Al}_{2} \mathrm{O}_{3}$ & 17.34 & 17.05 & 17.41 & 16.26 & 16.96 & 16.67 & 16.48 & 16.20 & 17.15 & 15.06 & 17.20 & 14.53 & 15.47 & 15.51 & 15.90 & 15.57 & 16.08 & 17.22 & 17.17 & 17.20 & 17.5 \\
\hline $\mathrm{Fe}_{2} \mathrm{O}_{3}$ & 11.12 & 8.66 & 8.69 & 11.12 & 10.52 & 9.33 & 10.20 & 10.38 & 9.90 & 10.48 & 9.41 & 12.06 & 10.51 & 12.26 & 12.64 & 11.63 & 10.42 & 6.64 & 6.77 & 9.85 & 9.7 \\
\hline $\mathrm{MnO}$ & 0.30 & 0.33 & 0.17 & 0.18 & 0.13 & 0.14 & 0.15 & 0.13 & 0.14 & 0.13 & 0.14 & 0.18 & 0.18 & 0.16 & 0.17 & 0.18 & 0.17 & 0.10 & 0.10 & 0.19 & 0.2 \\
\hline $\mathrm{MgO}$ & 4.80 & 6.07 & 5.91 & 6.40 & 7.63 & 8.42 & 7.22 & 7.66 & 8.29 & 9.92 & 10.00 & 7.35 & 6.75 & 6.15 & 3.51 & 4.88 & 5.03 & & 1.53 & & 4.4 \\
\hline $\mathrm{CaO}$ & 12.01 & 12.27 & 10.86 & 11.41 & 10.32 & 9.65 & 11.33 & 10.45 & 10.72 & 9.66 & 10.24 & 11.21 & 12.33 & 11.68 & 13.11 & 12.15 & 12.11 & 4.87 & 4.94 & 7.19 & 7.0 \\
\hline $\mathrm{Na}_{2} \mathrm{O}$ & 3.21 & 3.34 & 3.45 & 3.00 & 2.68 & 2.71 & 2.82 & 2.72 & 2.80 & 2.17 & 2.50 & 2.94 & 3.10 & 2.64 & 3.06 & 3.01 & 3.45 & 4.26 & 4.28 & 2.68 & 2.9 \\
\hline $\mathrm{K}_{2} \mathrm{O}$ & 0.07 & 0.06 & 0.09 & 0.08 & 0.08 & 0.08 & 0.09 & 0.08 & 0.08 & 0.09 & 0.08 & 0.15 & 0.09 & 0.44 & 0.29 & 0.43 & 0.24 & 2.83 & 2.90 & 1.71 & 1.7 \\
\hline $\mathrm{P}_{2} \mathrm{O}_{5}$ & 0.20 & 0.19 & 0.23 & 0.22 & 0.24 & 0.24 & 0.24 & 0.25 & 0.20 & 0.21 & 0.19 & 0.25 & 0.21 & 0.26 & 0.30 & 0.28 & 0.25 & 0.48 & 0.49 & 0.28 & 0.2 \\
\hline L.O.I. & 1.28 & 1.16 & 1.41 & 1.96 & 1.01 & 2.00 & 2.03 & 2.92 & 1.78 & 3.68 & 2.28 & 2.09 & 0.47 & 1.86 & 3.26 & 2.82 & 1.56 & & & & \\
\hline mg & 49.6 & 61.4 & 60.8 & 56.7 & 62.3 & 67.3 & 61.7 & 62.7 & 65.6 & 68.3 & 71.0 & 58.1 & 59.4 & 53.3 & 38.7 & 48.9 & 52.4 & & & & \\
\hline v & 254 & 244 & 242 & 229 & 227 & 238 & 219 & 222 & 233 & 196 & 196 & 280 & 307 & 314 & 311 & 311 & 289 & 118 & 124 & 223 & 225 \\
\hline $\mathrm{Cr}$ & 295 & 310 & 290 & 262 & 255 & 270 & 250 & 244 & 287 & 222 & 257 & 279 & 339 & 333 & 284 & 267 & 272 & 13 & 11 & 44 & 42 \\
\hline $\mathrm{Ni}$ & 121 & 139 & 102 & 124 & 131 & 126 & 121 & 127 & 123 & 107 & 138 & 88 & 85 & 87 & el & 99 & 99 & 14 & 16 & 16 & 16 \\
\hline Co & 52 & 53 & 45 & 33 & 44 & 42 & 41 & 42.5 & 47 & 37 & 46 & 38 & 44 & 41 & 34 & 22 & 48 & 15 & 16 & 38 & 35 \\
\hline $\mathrm{Rb}$ & 2 & n.d. & 1 & 2 & 1 & 1 & 1 & 1 & 1 & 2 & n.d. & 3 & n.d. & 13 & 6 & 12 & 6 & 67 & 67 & 74 & 70 \\
\hline $\mathrm{Ba}$ & 24 & & 26 & 23 & 31 & 26 & 27 & 21 & & 24 & & 35 & & 35 & 42 & 40 & & 1241 & 1209 & 407 & 385 \\
\hline $\mathrm{Sr}$ & 220 & 219 & 217 & 223 & 225 & 208 & 210 & 200 & 194 & 178 & 180 & 190 & 192 & 204 & 252 & 251 & 232 & 679 & 659 & 403 & 400 \\
\hline $\mathrm{Zr}$ & 116 & 115 & 118 & 113 & 106 & 116 & 112 & 110 & 112 & 98 & 103 & 107 & 116 & 113 & 148 & 143 & 160 & 229 & 227 & 132 & 125 \\
\hline $\mathrm{Nb}$ & 2 & 3 & 3 & 2 & 2 & 3 & 2 & 2 & 3 & 2 & 2 & 5 & 4 & 5 & 6 & 5 & 4 & 14 & 15 & 7 & 6 \\
\hline Y & 34 & 32 & 36 & 36 & 34 & 33 & 34 & 33 & 30 & 29 & 28 & 35 & 32 & 39 & 44 & 43 & 40 & 19 & 20 & 28 & 30 \\
\hline $\mathrm{Ti} / \mathrm{Zr}$ & 83 & 89 & 86 & 83 & 89 & 86 & 84 & 87 & 83 & 80 & 75 & 93 & 93 & 97 & 87 & 84 & 83 & & & & \\
\hline $\mathrm{Zr} / \mathrm{Nb}$ & 58 & 38 & 39 & 57 & 53 & 39 & 56 & 55 & 36 & 49 & 52 & 21 & 29 & 23 & 25 & 29 & 41 & & & & \\
\hline $\mathrm{Zr} / \mathrm{Y}$ & 3.4 & 3.6 & 3.3 & 3.1 & 3.1 & 3.5 & 3.3 & 3.3 & 3.7 & 3.4 & 3.7 & 3.1 & 3.6 & 2.9 & 3.4 & 3.3 & 3.8 & & & & \\
\hline $\mathrm{Ba} / \mathrm{Nb}$ & 12 & & 9 & 12 & 16 & 9 & 14 & 11 & & 12 & & 7 & & 7 & 7 & 8 & & & & & \\
\hline $\mathrm{K} / \mathrm{Nb}$ & 291 & 166 & 242 & 324 & 334 & 221 & 380 & 339 & 211 & 373 & 332 & 249 & 187 & 731 & 401 & 714 & 543 & & & & \\
\hline La & 5.28 & & 4.03 & 4.70 & 3.61 & 3.75 & 3.01 & 4.14 & & 3.41 & & 7.00 & & 4.30 & 6.14 & 7.89 & & & & & \\
\hline $\mathrm{Ce}$ & 16.8 & & 14.2 & 17.1 & 12.4 & 13.9 & 11.2 & 16.2 & & 11.8 & & 22.3 & & 14.8 & 17.5 & 24.1 & & & & & \\
\hline $\mathrm{Nd}$ & 13.7 & & 12.3 & 13.3 & 10.4 & 11.3 & 9.58 & 11.8 & & 8.85 & & 18.4 & & 10.9 & 14.3 & 19.8 & & & & & \\
\hline Sm & 5.46 & & 4.38 & 4.78 & 3.96 & 3.82 & 3.32 & 4.37 & & 3.21 & & 6.31 & & 3.55 & 4.88 & 7.06 & & & & & \\
\hline Eu & 1.64 & & 1.47 & 1.48 & 1.22 & 1.32 & 1.14 & 1.32 & & 1.15 & & 1.66 & & 1.22 & 1.66 & 1.93 & & & & & \\
\hline Gd & 6.36 & & 5.52 & 6.60 & 4.72 & 4.78 & 3.78 & 4.70 & & 3.50 & & 7.80 & & 4.83 & 5.57 & 8.47 & & & & & \\
\hline Dy & 6.10 & & 4.76 & 5.80 & 4.31 & 4.35 & 4.39 & 4.64 & & 4.09 & & 7.20 & & 5.17 & 5.81 & 8.20 & & & & & \\
\hline Er & 3.54 & & 2.98 & 3.22 & 2.62 & 2.74 & 2.60 & 3.01 & & 2.38 & & 4.11 & & 2.73 & 3.57 & 4.61 & & & & & \\
\hline Yb & 3.20 & & 2.59 & 2.90 & 2.45 & 2.47 & 2.41 & 2.50 & & 2.23 & & 3.70 & & 2.91 & 3.25 & 4.20 & & & & & \\
\hline Lu & 0.56 & & 0.50 & 0.54 & 0.44 & 0.46 & 0.38 & 0.48 & & 0.42 & & 0.65 & & 0.49 & 0.58 & 0.72 & & & & & \\
\hline 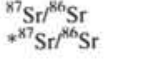 & & & & & & $\begin{array}{l}0.70317(3) \\
0.70265(3)\end{array}$ & & & & & & & $\begin{array}{l}0.70343(15) \\
0.70293(3)\end{array}$ & & & & $\begin{array}{l}0.70339(9) \\
0.70271(3)\end{array}$ & & & & \\
\hline${ }^{143} \mathrm{Nd} /{ }^{144} \mathrm{Nd}$ & & & & & & $0.51314(6)$ & & & & & & & & & & & $0.51326(12)$ & & & & \\
\hline
\end{tabular}

te: $\mathrm{mg}=\mathrm{MgO} /\left(\mathrm{MgO}+\mathrm{FeO}\right.$ ) mol\%, assuming $\mathrm{Fe}_{2} \mathrm{O}_{3}=0.15 \mathrm{FeO}$. n.d.= not detected. Asterisk denotes ${ }^{x 7} \mathrm{Sr} /{ }^{76} \mathrm{Sr}$ ratios on $\mathrm{HCl} 2.5 \mathrm{~N}$ leached samples. Analyses of chemical reference standards $\mathrm{AGV}$ I and DRN are also reported (column $\mathrm{A}$ ) with recommended values (column B). 


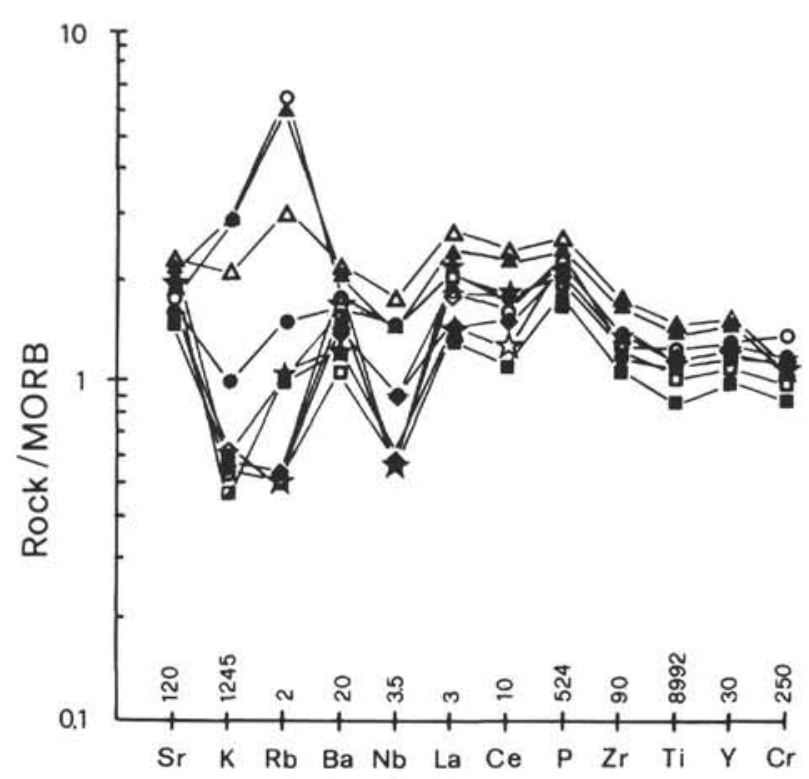

Nankai Trough

Hole 131-808C-

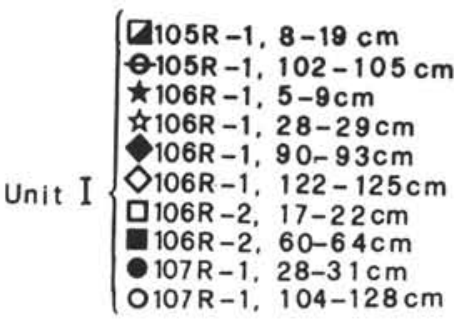

Unit II $\begin{cases}\Delta 108 R-1, & 63-66 \mathrm{~cm} \\ \mathbf{A} 108 \mathrm{R}-1, & 118-121 \mathrm{~cm}\end{cases}$

Figure 5. MORB-normalized patterns for incompatible element plus $\mathrm{Cr}$ for Nankai Trough basement rocks. Normalizing values after Pearce (1982).

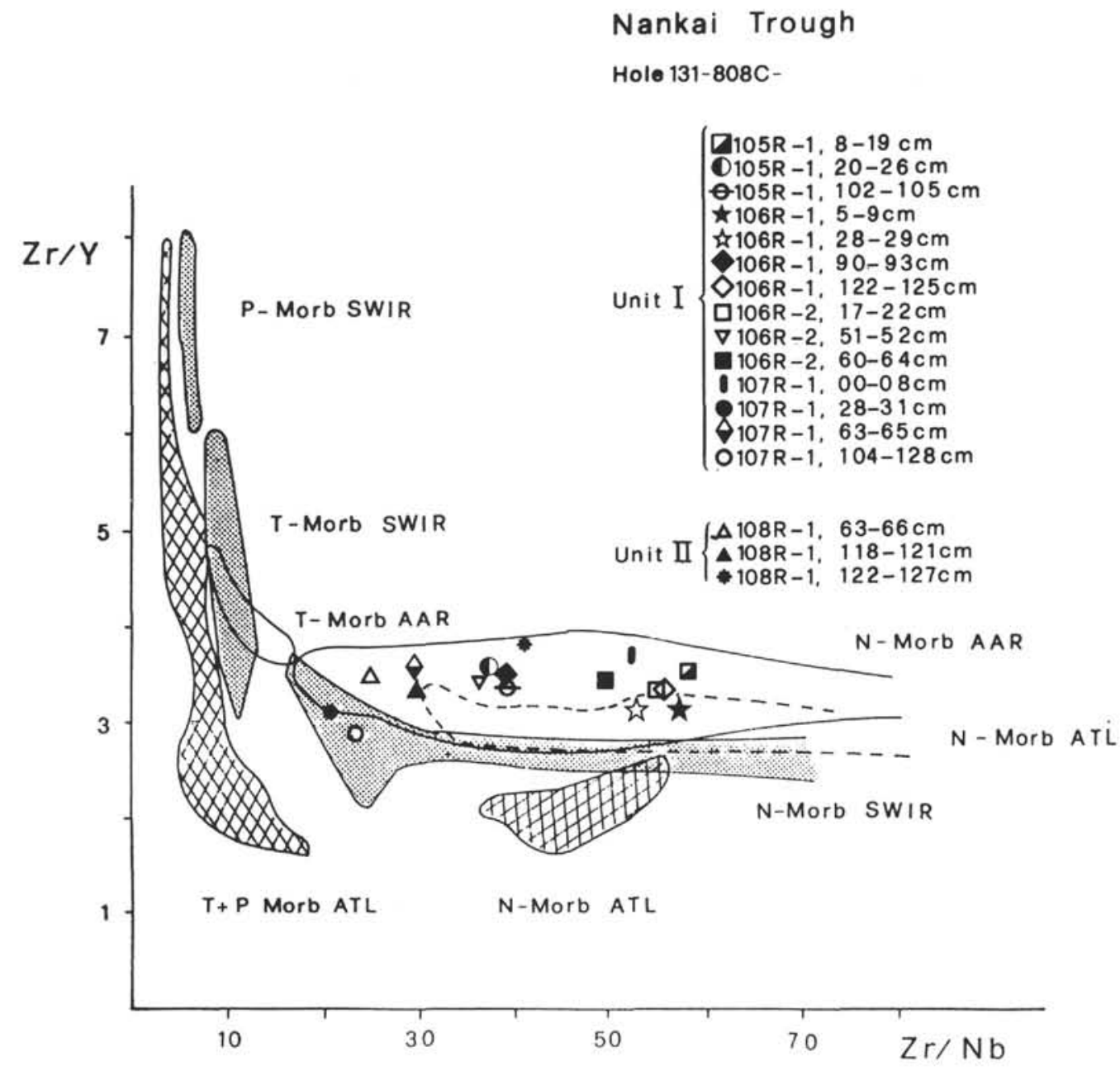

Figure 6. $\mathrm{Zr} / \mathrm{Y}$ vs. Zr/Nb discrimination diagram for Nankai Trough basaltic rocks. Fields for P-, T-, and N-MORB from southwest Indian Ridge (SWIR), American Antarctic Ridge (AAR), and Atlantic Ridge (ATL), are also reported for comparison. 


\section{Nankai Trough}

Hole 131-808C-

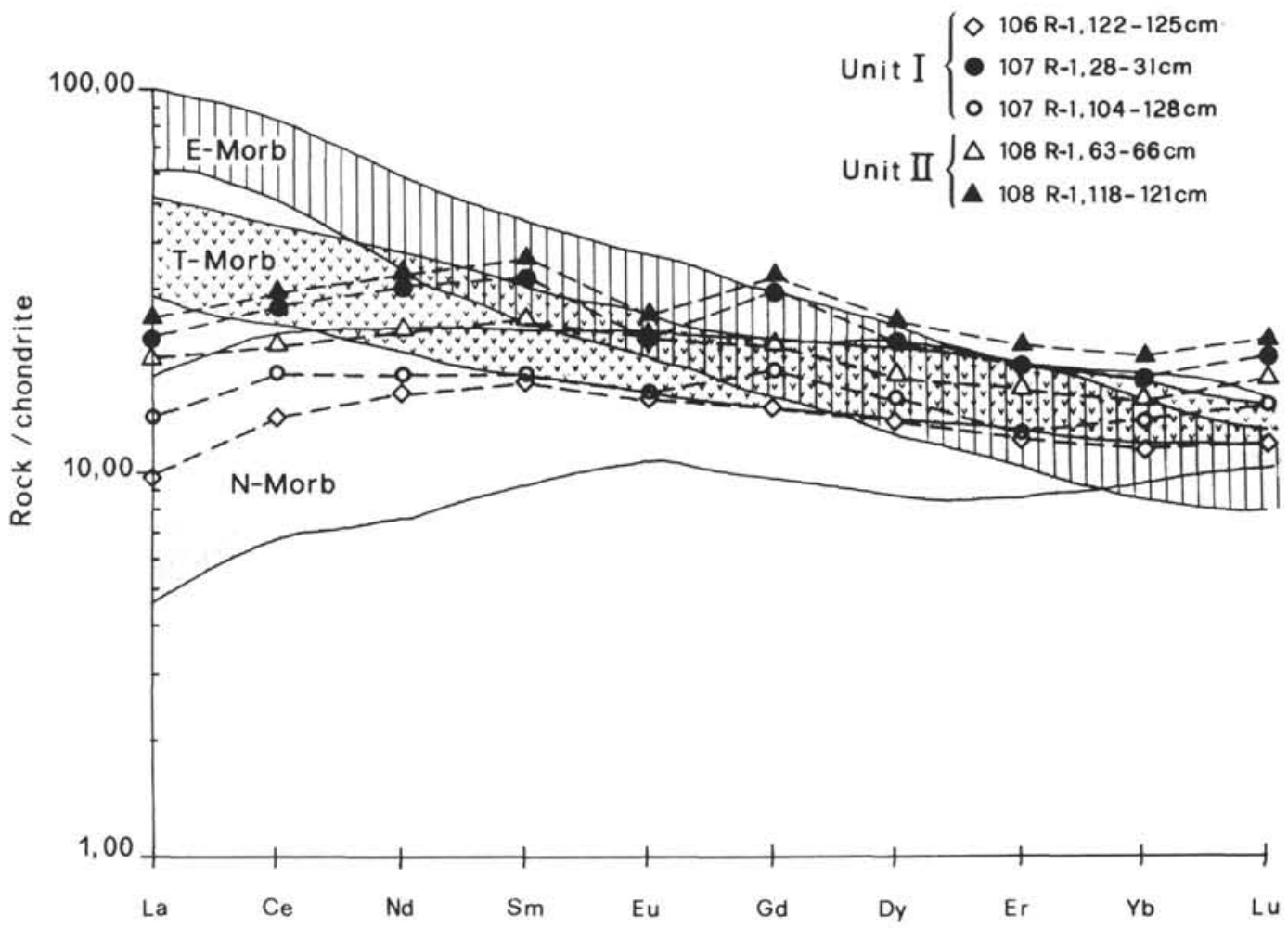

Figure 7. Chondrite-normalized REE patterns for representative Nankai Trough basement rocks. Normalizing values according to Taylor and Gorton (1977) are given. Fields for N-, T-, and E-MORB are from Le Roex (1987).

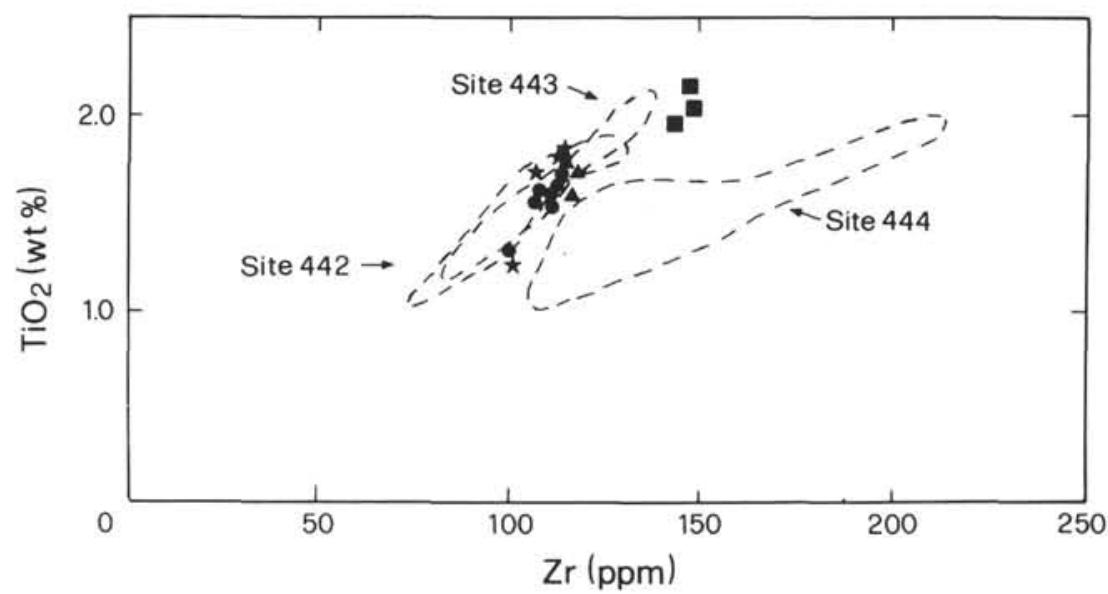

Figure $8 . \mathrm{TiO}_{2}$ vs. $\mathrm{Zr}$ diagram for Nankai Trough basalts (Hole $808 \mathrm{C}$ ). Symbols: triangles: Core 105; dots: Core 106; stars: Core 107; squares: Core 108 (pillow lavas). Fields for Sites 442, 443 , and 444 (Shikoku Basin) are reported for comparison (after Marsh et al., 1980). 